\title{
Tenascins and the Importance of Adhesion Modulation
}

\author{
Ruth Chiquet-Ehrismann ${ }^{1}$ and Richard P. Tucker ${ }^{2}$ \\ ${ }^{1}$ Friedrich Miescher Institute for Biomedical Research, Novartis Research Foundation, CH-4058 Basel, \\ Switzerland \\ ${ }^{2}$ Department of Cell Biology and Human Anatomy, University of California at Davis, Davis, \\ California 95616 \\ Correspondence: ruth.chiquet@fmi.ch
}

\begin{abstract}
Tenascins are a family of extracellular matrix proteins that evolved in early chordates. There are four family members: tenascin- $X$, tenascin- $R$, tenascin- $W$, and tenascin- $C$. Tenascin- $X$ associates with type I collagen, and its absence can cause Ehlers-Danlos Syndrome. In contrast, tenascin- $\mathrm{R}$ is concentrated in perineuronal nets. The expression of tenascin-C and tenascin-W is developmentally regulated, and both are expressed during disease (e.g., both are associated with cancer stroma and tumor blood vessels). In addition, tenascin- $C$ is highly induced by infections and inflammation. Accordingly, the tenascin-C knockout mouse has a reduced inflammatory response. All tenascins have the potential to modify cell adhesion either directly or through interaction with fibronectin, and celltenascin interactions typically lead to increased cell motility. In the case of tenascin-C, there is a correlation between elevated expression and increased metastasis in several types of tumors.
\end{abstract}

\section{THE DISCOVERY OF TENASCIN-C}

The first member of the tenascin family, tenascin-C, was discovered independently in laboratories studying subjects as different as the extracellular matrix in brain cancer (glioma mesenchymal extracellular matrix antigen), the components of myotendinous junctions (myotendinous antigen), or the embryonic development of the nervous system (cytotactin) and J1 glycoprotein (for references, see Table 1). Important functions were postulated for the protein, ranging from a structural role in muscle-tendon attachment to cell migration and cell-cell interactions in organ development. However, the first description of a function of tenascin- $\mathrm{C}$ was actually published long before anything was known about the existence of this protein when Ken Yamada and coworkers described the hemagglutinating activity of the major cell surface protein of chick embryo fibroblasts (Yamada et al. 1975). Almost a decade later Erickson and Iglesias used electron microscopy to analyze similar cell surface protein preparations, which were known to contain fibronectin, and found six-armed

Editors: Richard Hynes and Kenneth Yamada

Additional Perspectives on Extracellular Matrix Biology available at www.cshperspectives.org

Copyright (C) 2011 Cold Spring Harbor Laboratory Press; all rights reserved; doi: 10.1101/cshperspect.a004960

Cite this article as Cold Spring Harb Perspect Biol 2011;3:a004960 
R. Chiquet-Ehrismann and R.P. Tucker

Table 1. The tenascins.

\begin{tabular}{lll}
\hline Name & Discovery and synonyms & References \\
\hline Tenascin-C & $\begin{array}{l}\text { Glioma mesenchymal extracellular } \\
\text { matrix antigen (GMEM) } \\
\text { Myotendinous antigen }\end{array}$ & Bourdon et al. 1983 \\
& Cytotactin & Chiquet and Fambrough 1984 \\
& J1 glycoprotein & Grumet et al. 1985 \\
Tenascin-R & J1 160/J1 180 & Kruse et al. 1985 \\
& Restrictin & Pesheva et al. 1989; Fuss et al. 1993 \\
& & Rathjen et al. 1991; Norenberg et al. 1992; \\
Tenascin-X & Human gene X & Brummendorf et al. 1993 \\
& Tenascin-Y & Morel et al. 1989 \\
Tenascin-W & Tenascin-W & Hagios et al. 1996 \\
& & Weber et al. 1998; Scherberich et al. 2004; \\
& Tenascin-N* & Degen et al. 2007 \\
& & Neidhardt et al. 2003 \\
\hline
\end{tabular}

*Tenascin-W was first described in zebrafish (Weber et al. 1998) and later in mouse, where the orthologous protein was named tenascin-N (Neidhardt et al. 2003) before its relationship to tenascin-W was clarified (Scherberich et al. 2004; Tucker et al. 2006). The mouse and human tenascin-W genes, but not the genes in other species, are named tnn for this reason.

\begin{abstract}
"hexabrachions" in addition to two-armed fibronectin molecules (Erickson and Inglesias 1984). Shortly thereafter, Chiquet-Ehrismann and coworkers showed that the hemagglutinating activity originally attributed to fibronectin was actually the function of the hexabrachions, which they named tenascin (ChiquetEhrismann et al. 1986). When other members of this gene family were eventually identified (tenascin-R, tenascin-W, and tenascin-X), the original tenascin was renamed tenascin- $C$, the "C" representing "cytotactin". It was certainly not by chance that tenascin- $\mathrm{C}$ was isolated together with fibronectin: the two proteins not only bind to each other, they also are similar in size and structure and are often coexpressed. As shown in Figure 1, tenascins and fibronectins are only found in chordates, and the two proteins influence each other's effects on cell behavior.
\end{abstract}

\section{EVOLUTION AND EXPANSION OF THE TENASCIN FAMILY}

Tenascins appear to have evolved early in the chordate lineage (Fig. 1); that is, at a time roughly corresponding to the appearance of organisms belonging to the phylum to which vertebrates and a few invertebrates, such as sea squirts (Subphylum Urochordata, also known as tunicates) and the lancelet Branchiostoma floridae (Subphylum Cephalochordata, also known as amphioxus) belong. Both sea squirts and lancelets have tenascins with the identical general domain organization (heptad repeats, EGF-like repeats, FN3 domains, and a fibrinogen-related domain) as vertebrate tenascins, but no such genes could be found using similar approaches in echinoderms (e.g., sea urchins), protostomes like Drosophila or Caenorhabditis elegans, or cnidarians (the phylum to which Hydra and sea anemones belong) (Tucker and Chiquet-Ehrismann 2009a). Thus, tenascins are relatively new additions to the extracellular matrix, appearing in the first organisms with a dorsal hollow nerve cord and neural crest cells or neural crest-like properties, as well as a pharyngeal apparatus and notochord. This is intriguing, as tenascin- $\mathrm{C}$ is prominently expressed by neural crest cells (Tucker and McKay 1991) and can be required for their normal migration (Tucker 2001), and tenascin-C and its relative tenascin- $\mathrm{W}$ are expressed in dense connective tissues like cartilage and bone (e.g., see Mackie et al. 1987; Scherberich et al. 2004), which may have their origins in the notochord (Zhang and Cohn 2006) and pharyngeal arch mesenchyme (Hecht et al. 2008). Thus, 


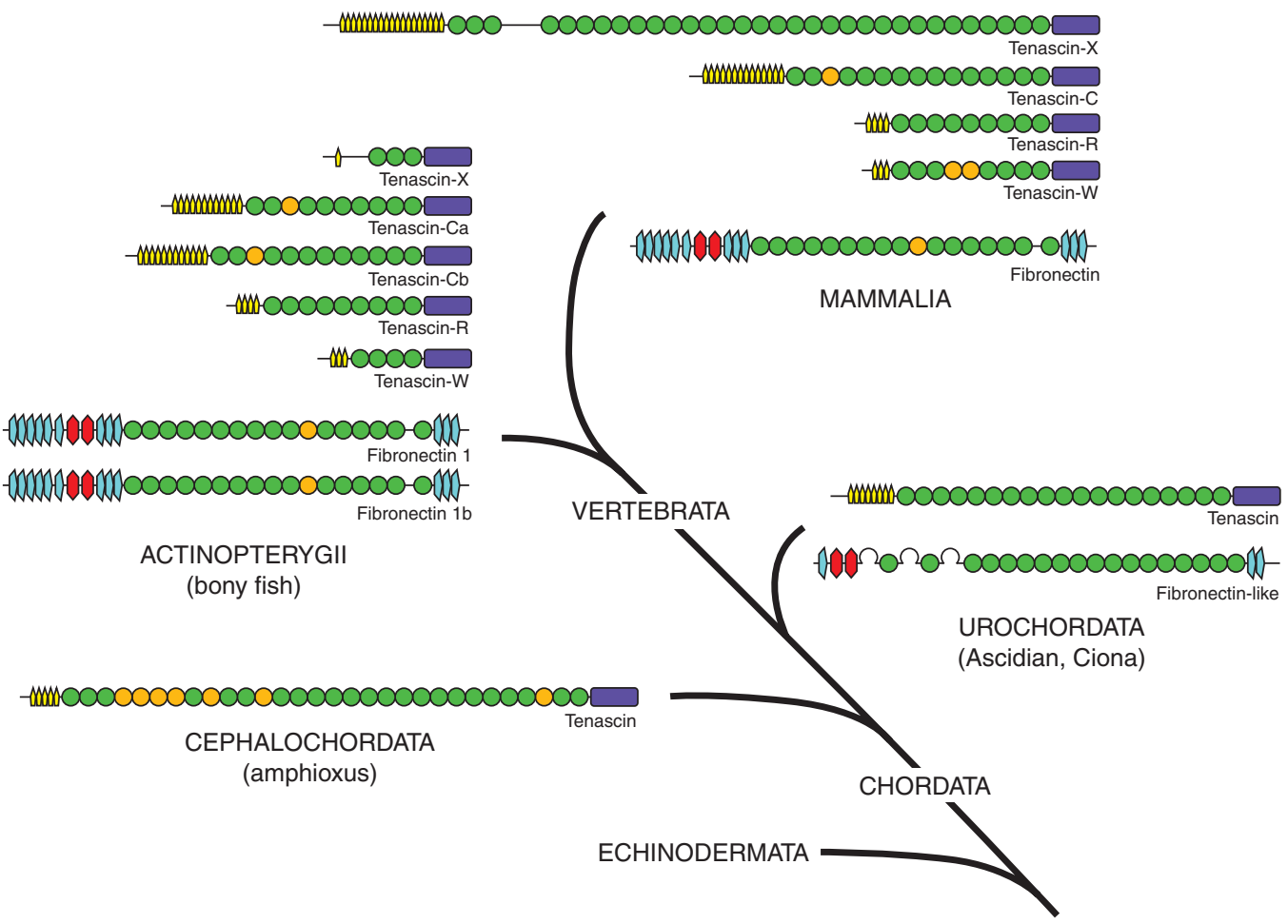

Figure 1. Tenascins and fibronectin are only found in Chordates. The tenascin gene from amphioxus (Cephalochordata) encodes a predicted protein with the characteristic organization of tenascins: one or more EGF-like repeats near the amino terminus (yellow pentagons), FN3 domains (circles), and a carboxy-terminal fibrinogen-related domain ( purple rectangle). FN3 domains with an RGD or KGD motif appropriately exposed for integrin binding are orange and those without are green. No fibronectin gene has been identified in amphioxus. In contrast, tunicates (Urochordata) have both a tenascin and a fibronectin-like gene. In mammals (adapted from human sequences here), there are four tenascin genes and a single fibronectin gene. In contrast, bony fish (Actinopterygii) have two fibronectin genes and the tenascin- $\mathrm{C}$ gene has duplicated. Representative proteins are illustrated here. Some are only predicted. In addition, some tenascins are known to have multiple splice variants that can result in different numbers of FN3 domains (see Fig. 2).

the evolution of tenascins is closely tied to the appearance of chordates, and may have played a key role in the development of their novel, defining structures.

The lancelet Branchiostoma floridae has a tenascin gene that is remarkably similar to a vertebrate tenascin. In addition to heptad repeats near the amino terminus that may support multimerization, it encodes five tenascin-type EGFlike repeats, 38 FN3 domains and a carboxyterminal fibrinogen-related domain. Seven of the FN3 domains have RGD motifs that are predicted to be exposed and available for integrin binding, which is suggestive or presumptive evidence that integrin-mediated signaling may be a fundamental tenascin function (Tucker and Chiquet-Ehrismann 2009a). Another early chordate, the sea squirt Ciona intestinalis, also has a tenascin gene. The predicted protein has heptad repeats, eight tenascin-type EGF-like repeats, $19 \mathrm{FN} 3$ domains and a carboxy-terminal fibrinogen-related domain (Tucker et al. 2006; Tucker and Chiquet-Ehrismann 2009a).

As will be described below, tenascin-C is able to influence cell spreading and proliferation via its interactions with fibronectin (Huang et al. 2001; Midwood et al. 2004), which led to the hypothesis that tenascins may have evolved, 
in part, to modulate fibronectin function. If true, one would expect that fibronectins evolved either before tenascins or at roughly the same time. Surprisingly, attempts to identify genes encoding FN1, FN2 and FN3 domains in a number of genomes reveal that fibronectin, though highly conserved in domain organization in vertebrates, is only found in organisms belonging to the Phylum Chordata (Tucker and Chiquet-Ehrismann 2009a; see also Whittaker et al. 2006). A fibronectin-like gene is found in the genome of the sea squirt Ciona savignyi (Tucker and Chiquet-Ehrismann 2009a), but no fibronectin-like genes could be found in the Branchiostoma floridae genome, even though it contains a tenascin gene. If amphioxus is more distantly related to vertebrates than the sea squirts, which is becoming more widely accepted (e.g., see Putnam et al. 2007), then tenascin may have evolved before fibronectin, not the other way around. Regardless of their precise origins, the first organisms that express both fibronectin and tenascin are the vertebrates, and their coexpression and interactions may have been fundamental to vertebrate evolution.

The literature contains a number of names for tenascins (Table 1). Some of these names were assigned before the relationship to the tenascin family was known, whereas others were named before it was recognized that the orthologous tenascin had already been described in another species. Studies of the evolution of tenascin genes have helped clarify the relationships between members of the gene family and have led to simplification of the tenascin nomenclature (Tucker et al. 2006). Therefore, in most vertebrates there are four tenascins: tenascin- $C$, which is the original "tenascin"; tenascin- $R$, with the " $R$ " standing for "restrictin"; tenascin-X, named after "human gene X"; and tenascin-W, named after its discoverer. Bony fish (Class Actinopterygii) have five tenascins (Fig. 1). The fifth tenascin in bony fish is a duplication of tenascin-C; the two paralogs are called tenascin-Ca and tenascin-Cb (Tucker et al. 2006). Note that an unexpressed tenascin pseudogene (tenascin-XB) found in mammalian genomes appears to have resulted from a duplication of the carboxy-terminal part of the tenascin- $X$ gene. The main features of the four mouse and human tenascins are summarized in Figure 2. The models depicted in Figure $2 \mathrm{~A}$ are based on the protein accession numbers given in Figure 2B, which also includes the chromosomal locations, major sites of expression, and human disease associations. Further variations in tenascins are obtained by alternative splicing, which is frequently observed in tenascin- $\mathrm{C}$ and also occurs in tenascin- $\mathrm{R}$ (Joester and Faissner 2001). The FN3 repeats subject to alternative splicing are colored in light green in Figure 2A. Alternative splicing has not been described for tenascin-W or tenascin-X.

\section{TENASCINS IN CELL ADHESION MODULATION}

One of the first observations testing tenascin- $\mathrm{C}$ as a substratum for cells in culture revealed that cells did not adhere well and proliferation was increased (Chiquet-Ehrismann et al. 1986). Tenascin-C even inhibited cell adhesion to fibronectin (Chiquet-Ehrismann et al. 1988; Lotz et al. 1989). This provided the basis for the new classification of a subgroup of extracellular matrix proteins as antiadhesive or adhesion-modulating extracellular matrix proteins (reviewed in Chiquet-Ehrismann 1991). Adhesion modulation has, in the meantime, become a well-recognized mechanism to influence cell proliferation, migration, differentiation, and anoikis (Murphy-Ullrich 2001). This theme is now very much under discussion in the fields of stem cell research as well as tissue engineering (for a recent review, see Guilak et al. 2009). Several mechanisms were found to be responsible for the antiadhesive effects of tenascin-C depending on the cells and the experimental paradigms used. In mixed substrata of fibronectin and tenascin- $\mathrm{C}$ the antiadhesive effect is mediated by binding of tenascin-C to the HepII/syndecan-4 binding site in the FN3-13 repeat of fibronectin, thereby inhibiting the coreceptor function of syndecan-4 in fibronectin-mediated cell spreading 
Tenascins and the Importance of Adhesion Modulation

A

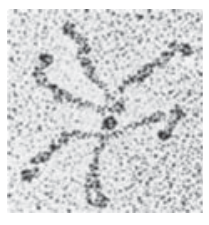

Tenascin-c -

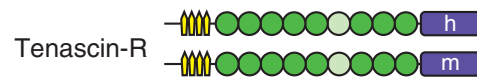

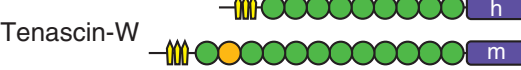

Tenascin-X

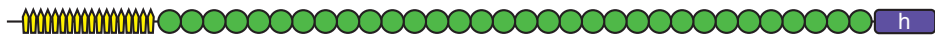
- $1000000000000000000000000000 \mathrm{~m}$ EGF-like repeats

FN3 domains

FReD

B

\begin{tabular}{|c|c|c|}
\hline $\begin{array}{l}\text { Tenascin: } \\
\text { Protein accession number/ } \\
\text { Chromosomal location }\end{array}$ & Main sites of expression & Disease association \\
\hline $\begin{array}{l}\text { C Human: CAA55309/9q33 } \\
\text { Mouse: NP_035737/4qC1 }\end{array}$ & $\begin{array}{l}\text { Embryo: nervous, skeletal, } \\
\text { and vascular systems, organ } \\
\text { morphogenesis } \\
\text { Adult: dense connective } \\
\text { tissues, some smooth muscle, } \\
\text { stem cell niches of brain and } \\
\text { bone marrow } \\
\end{array}$ & $\begin{array}{l}\text { Asthma } \\
\text { Fibrosis } \\
\text { Wound healing } \\
\text { Nerve regeneration } \\
\text { Infection and inflammation } \\
\text { Cancer stroma } \\
\text { Tumor angiogenesis } \\
\text { Tumor invasion and metastasis } \\
\end{array}$ \\
\hline $\begin{array}{l}\mathbf{R} \\
\text { Human: NP_003276/1q24 } \\
\text { Mouse: AAI38044/1qH2 }\end{array}$ & $\begin{array}{l}\text { Brain and peripheral nervous } \\
\text { system }\end{array}$ & \\
\hline $\begin{array}{l}\text { Wuman: NP_071376/1q23-24 } \\
\text { Mouse: AAI38336/1qH2 }\end{array}$ & $\begin{array}{l}\text { Bone, kidney, some smooth } \\
\text { muscle }\end{array}$ & $\begin{array}{l}\text { Cancer stroma } \\
\text { Tumor angiogenesis }\end{array}$ \\
\hline $\begin{array}{l}\text { Xuman: NP_061978/6p21.3 } \\
\text { Mouse: BAA24436/17qB1 }\end{array}$ & $\begin{array}{l}\text { Loose connective tissues, } \\
\text { epimysium, some smooth } \\
\text { muscle }\end{array}$ & $\begin{array}{l}\text { Ehlers-Danlos Syndrome (joint } \\
\text { and skin laxity and bruising) } \\
\text { COPD } \\
\text { Diverticulitis } \\
\text { Rectal and uterine prolapse }\end{array}$ \\
\hline
\end{tabular}

Figure 2. Main features of the four vertebrate tenascins. (A) Top left shows a tenascin-C hexabrachion revealed in an electron micrograph after rotary shadowing. Domain models of each tenascin family member are depicted for human and mouse orthologs as indicated by h (human) or $\mathrm{m}$ (mouse) within their fibrinogen-related domains (FReD). Heptad repeats for oligomerization are present close to the amino terminus indicated by a short black line in front of the EGF-like repeats shown in yellow and FN3 domains in dark green for the constant repeats, light green for FN3 repeats prone to alternative splicing, and orange for RGD-containing FN3 repeats. $(B)$ Accession numbers on which the models in $(A)$ are based and the chromosomal locations of the genes are given in the first column. Note that these protein sequences do not include certain extra repeats existing in rare splice variants. Main sites of expression are summarized as well as the major human or mouse disease associations found in the literature and cited in the main text.

(Huang et al. 2001; Midwood et al. 2004). In consequence, the activities of RhoA and focal adhesion kinase are compromised: cells redistribute their actin to the cell cortex and downregulate focal adhesion formation (Wenk et al. 2000; Midwood and Schwarzbauer 2002; Ruiz et al. 2004; Lange et al. 2007). This might be a general mechanism for adhesion modulation, because fibulin-1 was also shown to modulate cell adhesion to fibronectin in this way (Williams and Schwarzbauer 2009). Additional mechanisms of adhesion modulation by tenascin-C have been described that require cyclic GMP-dependent protein kinase (MurphyUllrich et al. 1991, 1996). Furthermore, tenascin-C can directly interact with various cell 
adhesion receptors and influence their activities (for extensive reviews, see Orend and Chiquet-Ehrismann 2006; Midwood and Orend 2009). The FN3 repeats subject to alternative splicing are also involved in the modulation of cell adhesion, and tenascin- $\mathrm{C}$ with extra repeats was shown to be more active than tenascin- $\mathrm{C}$ without extra repeats in inducing irregular cell spreading with formation of cortical membrane ruffles and cellular protrusions that contain filamentous actin and fascin (Fischer et al. 1997). A possible receptor mediating this effect could be annexin II, which was found to bind to the extra repeats of tenascin-C (Chung and Erickson 1994), and annexin II receptors on endothelial cells were shown to mediate several cell regulatory functions induced by tenascin-C, such as mitogenesis, cell migration, and loss of focal adhesions (Chung et al. 1996). Figure 3 shows two examples of cells plated on tenascin-C versus fibronectin demonstrating the morphological differences that result from culture on the respective extracellular matrix proteins.

Adhesion modulation effects have also been reported for the other tenascins. Tenascin- $\mathrm{R}$ inhibits adhesion of mesenchymal and neural cells to fibronectin (Pesheva et al. 1994). Osteosarcoma and bladder carcinoma cells adhere to a tenascin-X substratum, but they did not spread or assemble stress fibers (Elefteriou et al. 1999) and p38 MAPK was identified as the major mediator of tenascin-X-induced cell detachment of mouse L cells (Fujie et al. 2009). Addition of tenascin-W to the culture medium of cancer cells (Scherberich et al. 2005; Degen et al. 2007) as well as primary osteoblasts (Meloty-Kapella et al. 2006; Meloty-Kapella et al. 2008) stimulated their migration toward a fibronectin substratum in vitro. Thus, a common activity of all tenascins seems to be their ability to modulate cell adhesion and migration.

\section{REGULATION OF TENASCIN EXPRESSION}

From the very different expression patterns of the four tenascins, it follows that the regulation of expression must be very different (for recent reviews, see Chiquet-Ehrismann and Chiquet 2003; Tucker and Chiquet-Ehrismann 2009b). There seem to be two types of tenascins: those with widespread and steady expression

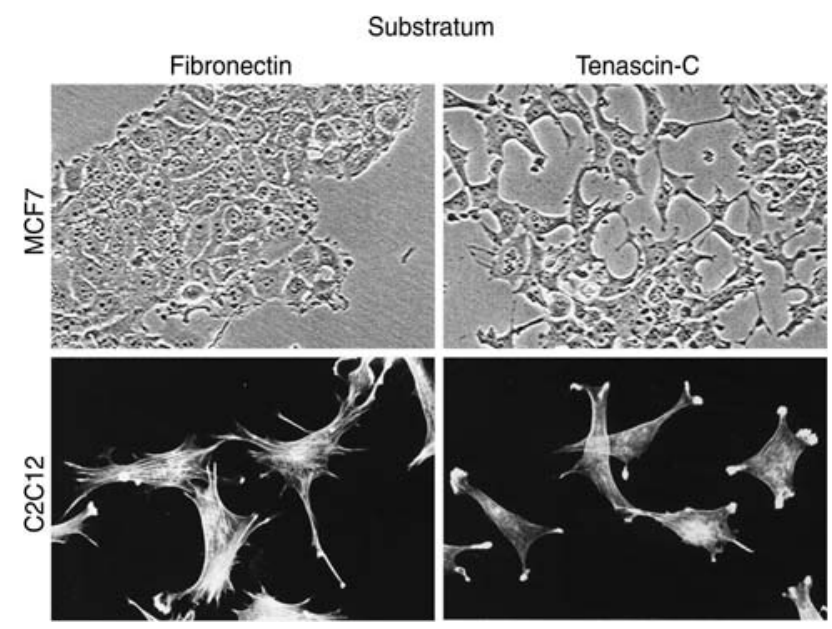

Figure 3. Adhesion modulation by tenascin-C. Cells adopt different morphologies depending on the substratum to which they are adhering. Although the MCF7 epithelial cancer cells form cell layers with close cell-cell contacts typical of epithelia on fibronectin, they disperse and lose their cell-cell contacts on a tenascin-C substratum, a process termed epithelial-mesenchymal transition (or EMT) that is important in cancer invasion. In addition, the myogenic/osteogenic mouse cell line $\mathrm{C} 2 \mathrm{C} 12$ reacts differently to these two substrata. As revealed by phalloidin staining the cells elaborate stress fibers on fibronectin while they concentrate F-actin in cell protrusions when plated on tenascin-C. 
throughout development and in the adult, and those with highly fluctuating expression patterns depending on the developmental stage and on intrinsically or extrinsically changing environments. Tenascin- $\mathrm{X}$ and tenascin- $\mathrm{R}$ belong to the former group; tenascin- $\mathrm{X}$ is expressed primarily by muscle and in loose connective tissues, whereas tenascin- $\mathrm{R}$ expression is limited to the nervous system. Tenascin- $\mathrm{C}$ and tenascin-W belong to the latter group. During development, tenascin-C is expressed during organ morphogenesis, and both tenascin- $\mathrm{C}$ and tenascin- $\mathrm{W}$ are expressed in the developing and adult skeleton. Tables summarizing the reported expression patterns of all tenascins can be found in Brellier et al. (2009). In addition, many pathological conditions including tumorigenesis, infection, and inflammation trigger tenascin- $\mathrm{C}$ expression (for a review, see Chiquet-Ehrismann and Chiquet 2003). Many different growth factors and cytokines are able to induce tenascin- $\mathrm{C}$ expression (for a review, see Orend and Chiquet-Ehrismann 2006; Tucker and Chiquet-Ehrismann 2009b), whereas less is known about the regulation of tenascin-W. There exist some common factors that lead to tenascin- $\mathrm{C}$ and tenascin-W expression in cultured cells, such as transforming growth factor $\alpha$ and transforming growth factor $\beta$ although the latter is more potent in inducing tenascin- $\mathrm{C}$ than tenascin- $\mathrm{W}$, whereas the opposite is the case for BMP2 (Scherberich et al. 2005). Activation of many of the major signaling pathways can lead to induction of tenascin- $\mathrm{C}$ and/or tenascin-W expression (Table 2). In turn, plating cells on tenascinC-containing substrata can affect several signaling pathways, such as induction of signaling through 14-3-3 tau (Wang et al.; Martin et al. 2003) MAPK and Wnt (Ruiz et al. 2004) or inhibition of the small GTPase RhoA known to induce actin stress fiber formation (Wenk et al. 2000). Thus, some of the same pathways that initially trigger tenascin- $\mathrm{C}$ expression potentially lead to negative (in the case of RhoA) or positive (in the case of MAPK and Wnt signaling) feedback loops. Another positive feedback loop may be the basis of chronic inflammation in arthritis, where inflammatory cytokines induce tenascin-C expression, which in turn activates TLR4 signaling in fibroblasts and myeloid cells leading to more cytokine production and more tenascin-C secretion. This establishes a vicious cycle causing chronic inflammation (Goh et al. 2010; Midwood et al. 2009).

Consistent with the many signaling pathways known to induce tenascin- $\mathrm{C}$ expression many transcription factors are known to stimulate tenascin- $\mathrm{C}$ transcription (Table 2) whereas GATA- 6 was identified as a transcriptional repressor of tenascin-C (Ghatnekar and Trojanowska 2008). In addition, tenascin-C can also be regulated at the transcript level by miR-335 (Tavazoie et al. 2008).

The least investigated aspect of tenascin- $\mathrm{C}$ regulation is its turnover at the protein level, although several proteases have been found to

Table 2. Signaling pathways and transcription factors that induce tenascin-C expression.

\begin{tabular}{llll}
\hline Signaling pathway & Reference & Transcription factor & Reference \\
\hline ROS/NFkB & Yamamoto et al. 1999 & Brn2 & Copertino et al. 1997 \\
ERK1/2 & Jones et al. 1999 & c-Jun, NFkB & Mettouchi et al. 1997 \\
Ras/MAPK & Maschler et al. 2004 & Prx1 & Jones et al. 2001 \\
Rho/ROCK & Chiquet et al. 2004; & Smad3/4, Sp1, & Jinnin et al. 2004; \\
& $\quad$ Sarasa-Renedo et al. 2006 & Ets1,2 CBP/p300 & Jinnin et al. 2006 \\
$\beta$-catenin/Wnt & Beiter et al. 2005; & Sox4 & Scharer et al. 2009 \\
& Cohen et al. 2008 & & \\
Notch & Sivasankaran et al. 2009 & RBPJk & Sivasankaran et al. 2009 \\
AKT/PI3K & Goh et al. 2010 & MEF2c with scleraxis & della Gaspera et al. 2009 \\
TLR4/NFkB & Goh et al. 2010 & EWS-ETS & Watanabe et al. 2003 \\
\hline
\end{tabular}


cleave tenascin-C (Mai et al. 2002; Imai et al. 1994; Siri et al. 1995). In the case of meprin $\beta$ and plasmin, digestion of tenascin- $\mathrm{C}$ converts it from an antiadhesive to an adhesive substratum (Gundersen et al. 1997; Ambort et al. 2010).

The promoter and the transcriptional regulation of tenascin-W remain to be determined. However, the promoters of tenascin- $\mathrm{R}$ and tenascin-X have been identified and studied. The promoters of human (Gherzi et al. 1998), rat (Leprini et al. 1998), and mouse tenascin-R (Putthoff et al. 2003) lack a TATA or CAAT box, GC-rich regions or initiator element. Sequences required for the neuronal expression of tenascin-R were identified within 57bp upstream of the transcription start site and in the first exon (Leprini et al. 1998; Putthoff et al. 2003), but the transcription factors involved are unknown. Several regions of the tenascin-X promoter were found to bind proteins by mobility shift assays and functionally important Sp1 binding sites were identified (Minamitani et al. 2000; Wijesuriya et al. 2002). Glucocorticoids inhibit tenascin-X expression in fibroblasts (Sakai et al. 1996). In this respect tenascin- $X$ is similar to tenascin-C, which is also negatively regulated by glucocorticoids (Chiquet-Ehrismann et al. 1995; Sakai et al. 1995).

\section{TENASCINS IN CELL MIGRATION, CANCER CELL INVASION, AND METASTASIS}

One of the main sites of expression of tenascin$\mathrm{C}$ and tenascin- $\mathrm{W}$ is the tumor microenvironment (for recent reviews, see Martina et al. 2010; Orend and Chiquet-Ehrismann 2006). In most epithelial cancers, the cellular source of tenascin-C and tenascin-W is not the tumor cells themselves, but rather tumor-associated fibroblasts residing in the tumor microenvironment. Immunohistochemical analyses of these tumors usually reveal a fibrous network of tenascin- $\mathrm{C}$ and tenascin-W enclosing unstained tumor nests. Examples of breast and colon carcinomas are shown in Figure 4. In other cancers such as melanoma or glioblastoma, the cancer cells themselves are secreting tenascin-C (Natali et al. 1990; Herlyn et al. 1991; Sivasankaran et al.
2009) and both tenascin-C as well as tenascin-W are present in brain cancer blood vessels (Higuchi et al. 1993; Zagzag et al. 1995; Kim et al. 2000; Martina et al. 2009). Tenascin-W staining correlates with von Willebrand factor staining, which is consistent with tenascin-W production by endothelial cells (Fig. 4). In contrast, tenascin-C staining correlates with desmin-expressing cells, demonstrating that the source of tenascin-C may be pericytes (Martina et al. 2009). Both tenascins have been shown to stimulate angiogenesis in vitro (Martina et al. 2009). Perivascular staining of tenascin-C was found to correlate with a shorter disease-free time in astrocytoma patients suggesting that tenascin-C may serve as a prognostic marker for an earlier tumor recurrence (Herold-Mende et al. 2002). In contrast to oligodendrogliomas, glioblastomas are rich in tenascin- $\mathrm{C}$ throughout the tumor, and tenascin- $\mathrm{C}$ has been associated with local invasion of this aggressive tumor type and stromal tenascin-C expression is correlated with shorter patient survival (Leins et al. 2003). Tenascin-C is strongly implicated in mediating the invasive behavior of glioma cells, and early studies showed that tenascin-C stimulated fibronectinmediated cell migration (Deryugina and Bourdon 1996). Similar observations have been made by several different research groups (Hirata et al. 2009; Sivasankaran et al. 2009); in one report, this migration was found to be dependent on the induction of metalloproteinase- 12 (Sarkar et al. 2006). The connection between tenascin-C expression and invasion is, however, not restricted to brain tumors. Also, in breast cancer tenascin- $C$ was observed at invasion borders and can serve as a predictor of both local and distant recurrence (Jahkola et al. 1998) and a higher risk of distant metastasis (Jahkola et al. 1996). A role for tenascin-C in metastasis promotion was also indicated by studies of a mouse xenograft model. It was found that miR335 suppresses metastasis by down-regulating Sox4 and tenascin-C (Tavazoie et al. 2008) and tenascin-C has recently been found to be a direct target of Sox4 (Scharer et al. 2009). Finally, tenascin- $C$ was found among the signature genes that mediate breast cancer 


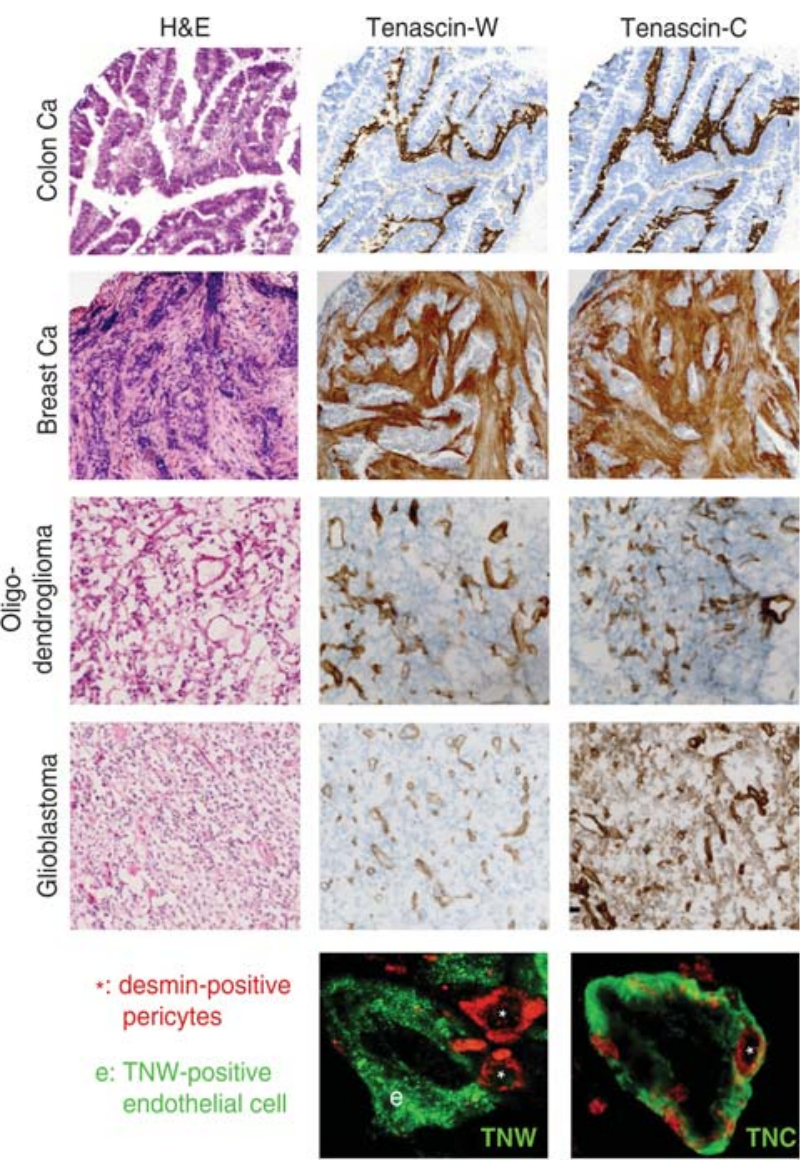

Figure 4. Tenascin- $\mathrm{C}$ and tenascin- $\mathrm{W}$ in cancer stroma. Immunostaining for tenascin-W and tenascin- $\mathrm{C}$ of sections of colon carcinoma (colon $\mathrm{Ca}$ ) and breast carcinoma (breast $\mathrm{Ca}$ ) reveal stromal staining in both cancer types (brown staining corresponding to the areas poor in nuclei visible in the corresponding H\&E stained adjacent sections). In brain cancer (oligodendroglioma and glioblastoma) tenascin-W is found around blood vessels while tenascin- $\mathrm{C}$ is in addition also detected throughout the entire glioblastoma tissue and is secreted by these highly invasive cancer cells. The lowest panels reveal that tenascin-W and tenascin- $\mathrm{C}$ are expressed by different blood vessel cells: tenascin-W seems to be made by endothelial cells, whereas tenascin-C is made by the surrounding desmin-positive pericytes.

metastasis to lung (Minn et al. 2005). A similar correlation has been found for tenascin-W in mouse models of mammary cancer, where stromal tenascin-W expression was particularly prominent in those cancers known to metastasize (Scherberich et al. 2005). So far such a correlation was not observed in human breast cancer where tenascin-W expression was higher in low-grade than in high-grade cancers (Degen et al. 2007). However, in colon cancer tenascin-W may correlate with the severity of the disease because serum levels of patients with nonmetastatic colon cancers were higher in those patients that suffered a recurrence (Degen et al. 2008).

We mentioned above the existence of distinct tenascin-C isoforms (see Fig. 2). It is interesting to note that larger isoforms are often tumor-specific. For example, in high-grade astrocytomas large tenascin- $\mathrm{C}$ variants containing the FN3-C domain are abundant around vascular structures and proliferating cells 
(Carnemolla et al. 1999). Also, FN3-B domain containing isoforms are associated with invasion fronts in ductal breast cancer (Tsunoda et al. 2003) and those with FN3-A1 domain are found in the majority of lymphomas (Schliemann et al. 2009). Part of the reason for the distinct isoform expression pattern between healthy and tumor tissues could be because the extracellular $\mathrm{pH}$ influences the splicing of tenascin-C mRNA (Borsi et al. 1996). Thus, large tenascin- $C$ isoforms might be expected to be enriched in tumors known to represent an acidic tissue. The presence of large tenascin- $\mathrm{C}$ variants in tumors can have additional functional consequences because this will also influence the susceptibility of tenascin-C to proteases (Siri et al. 1995; Ambort et al. 2010). The cancer-specific expression of large tenascin- $\mathrm{C}$ isoforms has also been exploited for targeted tumor therapy (Brack et al. 2006; Reardon et al. 2007). For tenascin-X and tenascin- $\mathrm{R}$ a connection to cancer has rarely been made. Thus, the tumor-specific functions described above are particularly important for tenascin-C and tenascin-W.

\section{TENASCIN FUNCTION INFERRED FROM MOUSE MODELS}

The initial studies of tenascin- $\mathrm{C}$ knockout mice did not report any obvious developmental abnormalities (Saga et al. 1992; Forsberg et al. 1996), but over time a number of important phenotypes have been observed (Table 3). The first of these described abnormal behavior (Fukamauchi et al. 1996; see also Kiernan et al. 1999), which was confirmed and thoroughly analyzed by Morellini and Schachner (2006). They found that the tenascin-C knockout mice have lower anxiety and increased activity, but normal coordination and cognitive skills. Detailed electrophysiological (Evers et al. 2002; Gurevicius et al. 2009) and morphometric (Irintchev et al. 2005; Gurevicius et al. 2009) studies of knockout mouse brains produced results that may help explain the behavioral changes. For example, the cerebral cortex of tenascin-C knockout mice has a higher neuronal density than the controls and its pyramidal cells have abnormal dendritic morphology.

Some organs featuring epithelial-mesenchymal interactions and branching morphogenesis are also abnormal in the tenascin- $\mathrm{C}$ knockout mice. When lungs are cultured from fetal knockout mice they have fewer end buds than controls and the end buds are larger (RothKleiner et al. 2004). This was confirmed in sections of the lungs of neonatal knockout mice, which also have larger air spaces than the controls. The prostates of the knockout mice are larger than in wild-type mice and feature multilayered epithelia, some of which protrude into the lumens of the ducts (Ishii et al. 2008).

Tenascin- $C$ is frequently encountered in stem cell niches, and hematopoiesis is abnormal in stem cells cultured from tenascin- $\mathrm{C}$ knockout mouse bone marrow (Ohta et al. 1998). Similarly, the tenascin-C found near glial precursors in the developing brain appears to be critical for their differentiation, migration, and survival (Garcion et al. 2001; Garcion et al. 2004; Garwood et al. 2004). However, the appearance of glial progenitors derived from the tenascinC-rich subependymal zone of the adult mouse is unaffected by knocking out tenascin-C (Kazanis et al. 2007). The latter is an important example of close analysis of a region with abundant tenascin- $C$ failing to show a phenotype in the knockouts, perhaps because its absence can be compensated for by other factors.

Some of the most interesting phenotypes observed in the tenascin-C knockout mice are seen in disease models or responses to trauma (Table 3). For example, tenascin-C knockout mice develop less severe asthma in a mouse model (Nakahara et al. 2006). This may be a reflection of the negative consequences of upregulation of tenascin-C expression commonly associated with inflammation. This was nicely illustrated by (Midwood et al. 2009), who showed that tenascin-C knockout mice are protected from arthritis-like damage following the injection of an antigen into the knee joint. It seems that in the absence of tenascin- $\mathrm{C}$ mice are protected from chronic inflammation. A connection between tenascin- $\mathrm{C}$ and asthma has also been made in humans where it was 
Tenascins and the Importance of Adhesion Modulation

Table 3. Tenascin knockout mouse phenotypes.

\begin{tabular}{|c|c|c|}
\hline $\begin{array}{l}\text { Tenascin } \\
\text { knockout }\end{array}$ & Phenotypes & References \\
\hline \multirow[t]{9}{*}{ Tenascin- $\mathrm{C}$} & Abnormal behavior & \\
\hline & $\begin{array}{l}\text { Poor swimming, hyperlocomotion, } \\
\text { coordination deficits }\end{array}$ & Fukamauchi et al. 1996; Kiernan et al. 1999 \\
\hline & $\begin{array}{l}\text { Circadian rhythm defects, increased activity } \\
\text { in novel environments, reduced anxiety, } \\
\text { weak grip }\end{array}$ & Morellini and Schachner 2006 \\
\hline & \multicolumn{2}{|c|}{ Abnormal central nervous system development and organization } \\
\hline & $\begin{array}{l}\text { Increased migration and reduced } \\
\text { proliferation of oligodendrocyte } \\
\text { precursors }\end{array}$ & Garcion et al. 2001 \\
\hline & $\begin{array}{l}\text { Accelerated maturation of oligodendrocyte } \\
\text { precursors }\end{array}$ & Garwood et al. 2004 \\
\hline & $\begin{array}{l}\text { Effects on numbers of neurons and glia in } \\
\text { the hippocampus and cerebral cortex }\end{array}$ & Irintchev et al. 2005; Gurevicius et al. 2009 \\
\hline & Abnormal brain electrophysiology & $\begin{array}{l}\text { Evers et al. 2002; Andjus et al. 2005; } \\
\quad \text { Gurevicius et al. } 2009\end{array}$ \\
\hline & Effects on olfaction and olfactory bulb & de Chevigny et al. 2006; Treolar et al. 2009 \\
\hline
\end{tabular}

development

Abnormal stem cell niches

Reduced colony forming capacity of bone marrow cells

Abnormal neuronal stem cell niche

Abnormal branching morphogenesis

Reduced airway branching and larger air spaces

Abnormal prostate development

Abnormal responses to injury and stress

Susceptibility to glomerulonephritis

Prolonged dermatitis following application of hapten

Absence of migrating keratinocytes in corneal sutures

Abnormal regeneration, sprouting and reinnervation following peripheral nerve crushes or exposure to neurotoxins

Reduced angiogenesis around grafted melanoma cells

Attenuated response to vibrissectomy

Reduced recruitment of myofibroblasts after myocardial injury

Reduced neointimal cell migration and proliferation following aortotomy

Reduced bronchial asthma

Attenuated fibrosis during hepatitis

Atrophy of fast-muscle fibers following mechanical stress

Altered expression of inflammatory cytokines following CNS injury

Ohta et al. 1998

Garcion et al. 2004

Roth-Kleiner et al. 2004

Ishii et al. 2008

Nakao et al. 1998

Koyama et al. 1998

Matsuda et al. 1999

Cifuentes-Diaz et al. 1998; Cifuentes-Diaz et al. 2002; Guntinas-Lichius et al. 2005

Tanaka et al. 2004

Cybulska-Klosowicz et al. 2004

Tamaoki et al. 2005

Yamamoto et al. 2005

Nakahara et al. 2006

El-Karef et al. 2007

Flück et al. 2008

Ikeshima-Kataoka et al. 2008

(Continued on following page) 
R. Chiquet-Ehrismann and R.P. Tucker

Table 3. (Continued from previous page)

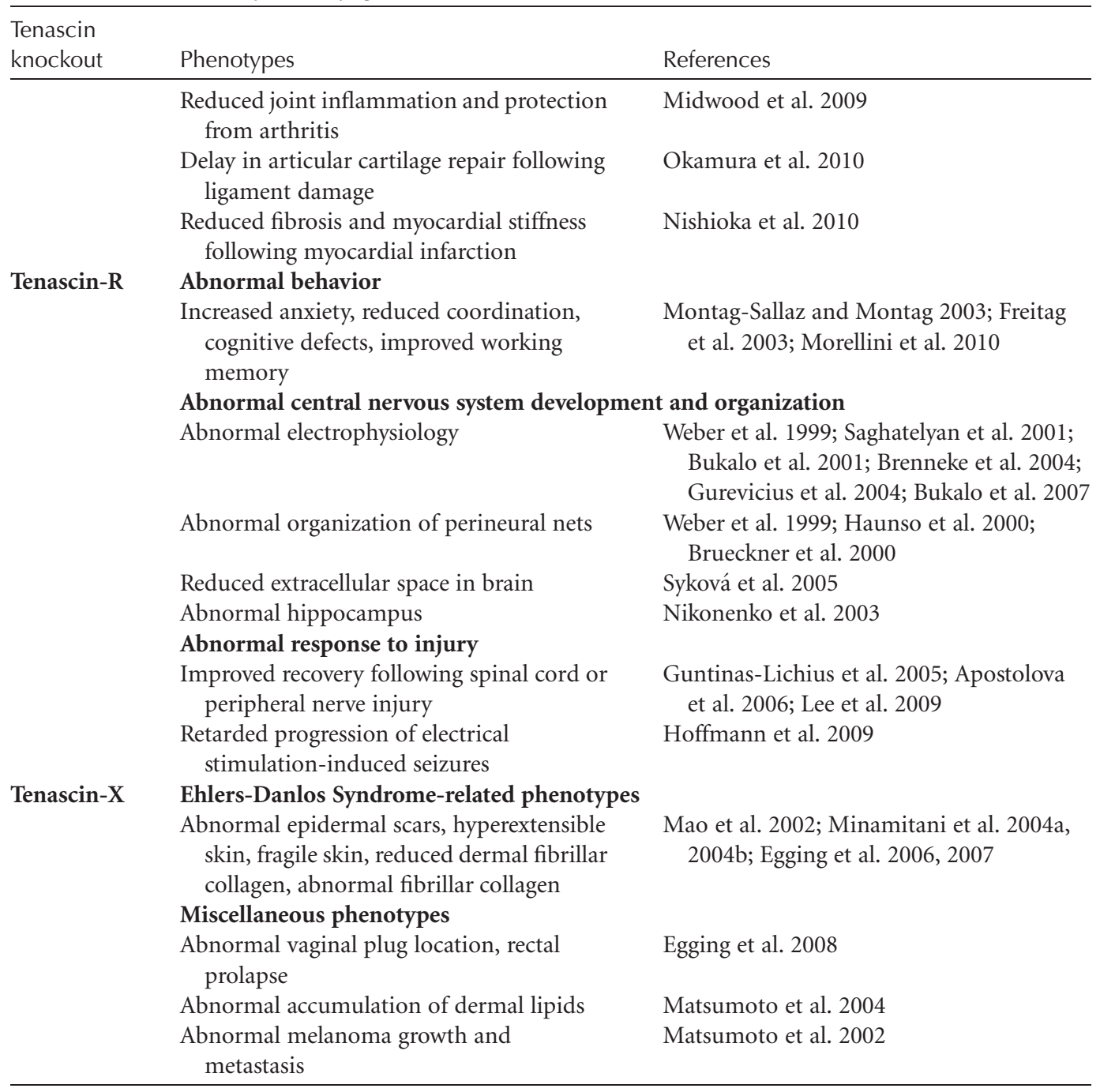

found that a coding SNP within an alternatively spliced FN3 domain strongly associates with adult bronchial asthma (Matsuda et al. 2005).

The tenascin- $\mathrm{R}$ knockout mice have neuronal phenotypes, as one would expect from the restricted pattern of tenascin- $\mathrm{R}$ expression (Table 3). The behavioral phenotypes are diametrically opposed to those observed in the tenascin-C knockouts: the tenascin-R knockout mice display more anxiety in an open field test, are uncoordinated, and have deficits in associative learning. Tenascin- $\mathrm{R}$ and tenascin- $\mathrm{C}$ both seem to be critical for normal development of the nervous system, but they appear to act on different parts of the brain.

The first morphological tenascin knockout phenotype came not from the mouse, but from a human: a 26-year-old man with EhlersDanlos Syndrome was shown to have a mutation that resulted in the loss of expression of tenascin-X (Burch et al. 1997). Ehlers-Danlos Syndrome is characterized as hyperextensible skin and joints, susceptibility to bruising, and poor wound healing. The role of tenascin-X in this syndrome, which previously was believed to be limited to collagens and enzymes that 
help modify and assemble collagens, was shown convincingly by the phenotype of the tenascinX knockout mouse (Table 3) (Mao et al. 2002; see also Egging et al. 2006). These mice have easily deformable skin and a significant decrease in the number of collagen fibrils in the dermis.

The expression of tenascins has also been shown to change when other genes are knocked out. Thus, the phenotypes associated with these mutants may, in part, be related to changes in tenascin expression. For example, knockout of $\mathrm{Bcl}-2$ results in abnormal vascular development and angiogenesis; endothelial cells isolated from these mice are less migratory and make less tenascin-C (Kondo et al. 2008). Knockouts of Smad8, which is part of the BMP signaling pathway, have increased levels of tenascin- $C$ expression in vascular smooth muscle and develop vascular pulmonary disease (Huang et al. 2009). Mice deficient in Msx2 show accelerated healing of skin wounds accompanied by increased tenascin- $\mathrm{C}$ expression in the granulation tissue (Yeh et al. 2009). Finally, tenascin-C levels are elevated when MMP-19, a protease that cleaves tenascin-C, is knocked out (Gueders et al. 2009). The MMP-19 knockouts are prone to airway inflammation after challenge with airborne allergens.

Phenotypes of tenascin- $\mathrm{C},-\mathrm{R}$, and $-\mathrm{X}$ knockout mice reveal critical roles for these proteins. Both tenascin- $\mathrm{C}$ and $-\mathrm{R}$ are required for normal development of the nervous system, and tenascin- $\mathrm{C}$ is required for normal responses to certain types of trauma. Tenascin-C does not appear to be necessary for the gross development of most nonneuronal tissues, but careful study shows that certain organ systems develop abnormally at the cellular level in the absence of tenascin-C. Tenascin-X is clearly required for the normal assembly and/or maintenance of the structural matrix of the dermis and other connective tissues. Future studies with tenascin$\mathrm{W}$ knockout animals may give insight into critical functions for this protein as well. Unfortunately, all tenascin knockout mice are "whole body" knockouts, which increases the likelihood that the genes of other extracellular matrix proteins or their receptors or any other type of compensatory machinery could be up-regulated or down-regulated to compensate for the missing tenascin. It would be interesting to see if Cre-mediated ablation of tenascin expression in a specific tissue and/or at a specific time in development would improve our understanding of tenascin functions.

In summary, there is clear evidence from these studies that tenascins can have structural roles as well as roles in cell signaling. An example of the former is tenascin-X, which is necessary for the structural integrity of connective tissues. Tenascin- $\mathrm{C}$ is an example of the latter. It is highly induced by many different challenges such as trauma, inflammation, or cancer development, and it seems to be involved in regenerative processes as well. It appears that tenascin- $\mathrm{C}$ is important in regulating cell proliferation and migration, and it affects differentiation during development as well as during regeneration and healing after insults. In both cases, the structural as well as the signaling functions, the exact molecular mechanisms underlying these activities remain to be determined.

\section{ACKNOWLEDGMENTS}

R.C-E. is supported by the Swiss National Science Foundation 31003A-120235.

\section{REFERENCES}

Ambort D, Brellier F, Becker-Pauly C, Stocker W, Andrejevic-Blant S, Chiquet M, Sterchi EE. 2010. Specific processing of tenascin-C by the metalloprotease meprin $\beta$ neutralizes its inhibition of cell spreading. Matrix Biol 29: $31-42$.

Andjus PR, Bajic A, Zhu L, Schachner M, Strata P. 2005. Short-term facilitation and depression in the cerebellum: Some observations on wild-type and mutant rodents deficient in the extracellular matrix molecule tenascin C. Ann N Y Acad Sci 1048: 185-197.

Apostolova I, Irintchev A, Schachner M. 2006. Tenascin-R restricts posttraumatic remodeling of motoneuron innervation and functional recovery after spinal cord injury in adult mice. J Neurosci 26: 7849-7859.

Beiter K, Hiendlmeyer E, Brabletz T, Hlubek F, Haynl A, Knol C, Kirchner T, Jung A. 2005. $\beta$-Catenin regulates the expression of tenascin-C in human colorectal tumors. Oncogene 24: 8200-8204.

Borsi L, Allemanni G, Gaggero B, Zardi L. 1996. Extracellular $\mathrm{pH}$ controls pre-mRNA alternative splicing of tenascin- $\mathrm{C}$ in normal, but not in malignantly transformed, cells. Int J Cancer 66: 632-635. 
R. Chiquet-Ehrismann and R.P. Tucker

Bourdon MA, Wikstrand CJ, Furthmayr H, Matthews TJ, Bigner DD. 1983. Human glioma-mesenchymal extracellular matrix antigen defined by monoclonal antibody. Cancer Res 43: 2796-2805.

Brack SS, Silacci M, Birchler M, Neri D. 2006. Tumor-targeting properties of novel antibodies specific to the large isoform of tenascin-C. Clin Cancer Res 12: 3200-3208.

Brellier F, Tucker RP, Chiquet-Ehrismann R. 2009. Tenascins and their implications in diseases and tissue mechanics. Scand J Med Sci Sports 19: 511-519.

Brenneke F, Bukalo O, Dityatev A, Lie AA. 2004. Mice deficient for the extracellular matrix glycoprotein tenascin-r show physiological and structural hallmarks of increased hippocampal excitability, but no increased susceptibility to seizures in the pilocarpine model of epilepsy. Neuroscience 124: 841-855.

Bruckner G, Grosche J, Schmidt S, Hartig W, Margolis RU, Delpech B, Seidenbecher CI, Czaniera R, Schachner M. 2000. Postnatal development of perineuronal nets in wild-type mice and in a mutant deficient in tenascin-R. J Comp Neurol 428: 616-629.

Brummendorf T, Hubert M, Treuber U, Leuschner R, Tarnok A, Rathjen FG. 1993. The axonal recognition molecule F11 is a multifunctional protein: Specific domains mediate interactions with $\mathrm{Ng}$-CAM and restrictin. Neuron 10: 711-727.

Bukalo O, Schachner M, Dityatev A. 2001. Modification of extracellular matrix by enzymatic removal of chondroitin sulfate and by lack of tenascin-R differentially affects several forms of synaptic plasticity in the hippocampus. Neuroscience 104: 359-369.

Bukalo O, Schachner M, Dityatev A. 2007. Hippocampal metaplasticity induced by deficiency in the extracellular matrix glycoprotein tenascin-R. J Neurosci 27: 60196028.

Burch GH, Gong Y, Liu W, Dettman RW, Curry CJ, Smith L, Miller WL, Bristow J. 1997. Tenascin-X deficiency is associated with Ehlers-Danlos syndrome [see comments]. Nat Genet 17: 104-108.

Carnemolla B, Castellani P, Ponassi M, Borsi L, Urbini S, Nicolo G, Dorcaratto A, Viale G, Winter G, Neri D, et al. 1999. Identification of a glioblastoma-associated tenascin- $\mathrm{C}$ isoform by a high affinity recombinant antibody. Am J Pathol 154: 1345-1352.

Chiquet-Ehrismann R. 1991. Anti-adhesive molecules of the extracellular matrix. Curr Opin Cell Biol 3: 800-804.

Chiquet-Ehrismann R, Chiquet M. 2003. Tenascins: Regulation and putative functions during pathological stress. J Pathol 200: 488-499.

Chiquet-Ehrismann R, Hagios C, Schenk S. 1995. The complexity in regulating the expression of tenascins. Bioessays 17: $873-878$.

Chiquet-Ehrismann R, Kalla P, Pearson CA, Beck K, Chiquet M. 1988. Tenascin interferes with fibronectin action. Cell 53: 383-390.

Chiquet-Ehrismann R, Mackie EJ, Pearson CA, Sakakura T. 1986. Tenascin: An extracellular matrix protein involved in tissue interactions during fetal development and oncogenesis. Cell 47: 131-139.

Chiquet M, Fambrough DM. 1984. Chick myotendinous antigen. II. A novel extracellular glycoprotein complex consisting of large disulfide-linked subunits. J Cell Biol 98: $1937-1946$.

Chiquet M, Sarasa-Renedo A, Tunc-Civelek V. 2004. Induction of tenascin-C by cyclic tensile strain versus growth factors: Distinct contributions by Rho/ROCK and MAPK signaling pathways. Biochim Biophys Acta 1693: 193-204.

Chung CY, Erickson HP. 1994. Cell surface annexin II is a high affinity receptor for the alternatively spliced segment of tenascin-C. J Cell Biol 126: 539-548.

Chung CY, Murphy-Ullrich JE, Erickson HP. 1996. Mitogenesis, cell migration, and loss of focal adhesions induced by tenascin-C interacting with its cell surface receptor, annexin II. Mol Biol Cell 7: 883-892.

Cifuentes-Diaz C, Faille L, Goudou D, Schachner M, Rieger F, Angaut-Petit D. 2002. Abnormal reinnervation of skeletal muscle in a tenascin-C-deficient mouse. J Neurosci Res 67: 93-99.

Cifuentes-Diaz C, Velasco E, Meunier FA, Goudou D, Belkadi L, Faille L, Murawsky M, Angaut-Petit D, Molgo J, Schachner M, et al. 1998. The peripheral nerve and the neuromuscular junction are affected in the tenascin-C-deficient mouse. Cell Mol Biol (Noisy-legrand) 44: 357-379.

Cohen ED, Tian Y, Morrisey EE. 2008. Wnt signaling: An essential regulator of cardiovascular differentiation, morphogenesis and progenitor self-renewal. Development 135: $789-798$.

Copertino DW, Edelman GM, Jones FS. 1997. Multiple promoter elements differentially regulate the expression of the mouse tenascin gene. Proc Natl Acad Sci 94: 1846-1851.

Cybulska-Klosowicz A, Zakrzewska R, Pyza E, Kossut M, Schachner M. 2004. Reduced plasticity of cortical whisker representation in adult tenascin-C-deficient mice after vibrissectomy. Eur J Neurosci 20: 1538-1544.

de Chevigny A, Lemasson M, Saghatelyan A, Sibbe M, Schachner M, Lledo PM. 2006. Delayed onset of odor detection in neonatal mice lacking tenascin-C. Mol Cell Neurosci 32: 174-186.

Degen M, Brellier F, Kain R, Ruiz C, Terracciano L, Orend G, Chiquet-Ehrismann R. 2007. Tenascin-W is a novel marker for activated tumor stroma in low-grade human breast cancer and influences cell behavior. Cancer Res 67: 9169-9179.

Degen M, Brellier F, Schenk S, Driscoll R, Zaman K, Stupp R, Tornillo L, Terracciano L, Chiquet-Ehrismann R, Ruegg C, et al. 2008. Tenascin-W, a new marker of cancer stroma, is elevated in sera of colon and breast cancer patients. Int J Cancer 122: 2454-2461.

della Gaspera B, Armand AS, Sequeira I, Lecolle S, Gallien CL, Charbonnier F, Chanoine C. 2009. The Xenopus MEF2 gene family: Evidence of a role for XMEF2C in larval tendon development. Dev Biol 328: 392-402.

Deryugina EI, Bourdon MA. 1996. Tenascin mediates human glioma cell migration and modulates cell migration on fibronectin. J Cell Sci 109: 643-652.

Egging DF, van Vlijmen-Willems I, Choi J, Peeters AC, van Rens D, Veit G, Koch M, Davis EC, Schalkwijk J. 2008. Analysis of obstetric complications and uterine connective tissue in tenascin-X-deficient humans and mice. Cell Tissue Res 332: 523-532. 
Tenascins and the Importance of Adhesion Modulation

Egging DF, van Vlijmen I, Starcher B, Gijsen Y, Zweers MC, Blankevoort L, Bristow J, Schalkwijk J. 2006. Dermal connective tissue development in mice: An essential role for tenascin-X. Cell Tissue Res 323: 465-474.

Egging D, van Vlijmen-Willems I, van Tongeren T, Schalkwijk J, Peeters A. 2007. Wound healing in tenascin-X deficient mice suggests that tenascin- $\mathrm{X}$ is involved in matrix maturation rather than matrix deposition. Connect Tissue Res 48: 93-98.

El-Karef A, Yoshida T, Gabazza EC, Nishioka T, Inada H, Sakakura T, Imanaka-Yoshida K. 2007. Deficiency of tenascin-C attenuates liver fibrosis in immune-mediated chronic hepatitis in mice. J Pathol 211: 86-94.

Elefteriou F, Exposito JY, Garrone R, Lethias C. 1999. Cell adhesion to tenascin-X mapping of cell adhesion sites and identification of integrin receptors. Eur J Biochem 263: $840-848$.

Erickson HP, Inglesias JL. 1984. A six-armed oligomer isolated from cell surface fibronectin preparations. Nature 311: 267-269.

Evers MR, Salmen B, Bukalo O, Rollenhagen A, Bosl MR, Morellini F, Bartsch U, Dityatev A, Schachner M. 2002. Impairment of L-type $\mathrm{Ca}^{2+}$ channel-dependent forms of hippocampal synaptic plasticity in mice deficient in the extracellular matrix glycoprotein tenascin-C. J Neurosci 22: 7177-7194.

Fischer D, Tucker RP, Chiquet-Ehrismann R, Adams JC. 1997. Cell-adhesive responses to tenascin-C splice variants involve formation of fascin microspikes. Mol Biol Cell 8: 2055-2075.

Fluck M, Mund SI, Schittny JC, Klossner S, Durieux AC, Giraud MN. 2008. Mechano-regulated tenascin-C orchestrates muscle repair. Proc Natl Acad Sci 105: $13662-13667$.

Forsberg E, Hirsch E, Frohlich L, Meyer M, Ekblom P, Aszodi A, Werner S, Fassler R. 1996. Skin wounds and severed nerves heal normally in mice lacking tenascin-C. Proc Natl Acad Sci 93: 6594-6599.

Freitag S, Schachner M, Morellini F. 2003. Behavioral alterations in mice deficient for the extracellular matrix glycoprotein tenascin-R. Behav Brain Res 145: 189-207.

Fujie S, Maita H, Ariga H, Matsumoto K. 2009. Tenascin-X induces cell detachment through p38 mitogen-activated protein kinase activation. Biol Pharm Bull 32: 17951799.

Fukamauchi F, Mataga N, Wang YJ, Sato S, Youshiki A, Kusakabe M. 1996. Abnormal behavior and neurotransmissions of tenascin gene knockout mouse. Biochem Biophys Res Commun 221: 151-156.

Fuss B, Wintergerst ES, Bartsch U, Schachner M. 1993. Molecular characterization and in situ mRNA localization of the neural recognition molecule J1-160/180: A modular structure similar to tenascin. J Cell Biol 120: 1237-1249.

Garcion E, Faissner A, ffrench-Constant C. 2001. Knockout mice reveal a contribution of the extracellular matrix molecule tenascin- $\mathrm{C}$ to neural precursor proliferation and migration. Development 128: 2485-2496.

Garcion E, Halilagic A, Faissner A, ffrench-Constant C. 2004. Generation of an environmental niche for neural stem cell development by the extracellular matrix molecule tenascin C. Development 131: 3423-3432.
Garwood J, Garcion E, Dobbertin A, Heck N, Calco V, ffrench-Constan C, Faissner A. 2004. The extracellular matrix glycoprotein Tenascin-C is expressed by oligodendrocyte precursor cells and required for the regulation of maturation rate, survival and responsiveness to plateletderived growth factor. Eur J Neurosci 20: 2524-2540.

Ghatnekar A, Trojanowska M. 2008. GATA-6 is a novel transcriptional repressor of the human Tenascin-C gene expression in fibroblasts. Biochim Biophys Acta 1779: $145-151$.

Gherzi R, Leprini A, Siri A, Zardi L. 1998. Structure of 5' region of human tenascin- $\mathrm{R}$ gene and characterization of its promoter. DNA Cell Biol 17: 275-282.

Goh FG, Piccinini AM, Krausgruber T, Udalova IA, Midwood KS. 2010. Transcriptional regulation of the endogenous danger signal tenascin-C: A novel autocrine loop in inflammation. J Immunol 184: 2655-2662.

Grumet M, Hoffman S, Crossin KL, Edelman GM. 1985. Cytotactin, an extracellular matrix protein of neural and non-neural tissues that mediates glia-neuron interaction. Proc Natl Acad Sci 82: 8075-8079.

Gueders MM, Hirst SJ, Quesada-Calvo F, Paulissen G, Hacha J, Gilles C, Gosset P, Louis R, Foidart JM, Lopez-Otin C, et al. 2009. MMP-19 deficiency promotes Tenascin- $\mathrm{C}$ accumulation and allergen-induced airway inflammation. Am J Respir Cell Mol Biol 43: 286-295.

Guilak F, Cohen DM, Estes BT, Gimble JM, Liedtke W, Chen CS. 2009. Control of stem cell fate by physical interactions with the extracellular matrix. Cell Stem Cell 5: 17-26.

Gundersen D, Tran-Thang C, Sordat B, Mourali F, Ruegg C. 1997. Plasmin-induced proteolysis of tenascin-C: Modulation by $\mathrm{T}$ lymphocyte-derived urokinase-type plasminogen activator and effect on T lymphocyte adhesion, activation, and cell clustering. J Immunol 158: 10511060.

Guntinas-Lichius O, Angelov DN, Morellini F, Lenzen M, Skouras E, Schachner M, Irintchev A. 2005. Opposite impacts of tenascin- $\mathrm{C}$ and tenascin- $\mathrm{R}$ deficiency in mice on the functional outcome of facial nerve repair. Eur J Neurosci 22: 2171-2179.

Gurevicius K, Gureviciene I, Valjakka A, Schachner M, Tanila H. 2004. Enhanced cortical and hippocampal neuronal excitability in mice deficient in the extracellular matrix glycoprotein tenascin-R. Mol Cell Neurosci 25: 515-523.

Gurevicius K, Kuang F, Stoenica L, Irintchev A, Gureviciene I, Dityatev A, Schachner M, Tanila H. 2009. Genetic ablation of tenascin-C expression leads to abnormal hippocampal CA1 structure and electrical activity in vivo. Hippocampus 19: 1232-1246.

Hagios C, Koch M, Spring J, Chiquet M, Chiquet-Ehrismann R. 1996. Tenascin-Y: a protein of novel domain structure is secreted by differentiated fibroblasts of muscle connective tissue. J Cell Biol 134: 1499-1512.

Haunso A, Ibrahim M, Bartsch U, Letiembre M, Celio MR, Menoud P. 2000. Morphology of perineuronal nets in tenascin-R and parvalbumin single and double knockout mice. Brain Res 864: 142-145.

Hecht J, Stricker S, Wiecha U, Stiege A, Panopoulou G, Podsiadlowski L, Poustka AJ, Dieterich C, Ehrich S, Suvorova $\mathrm{J}$, et al. 2008. Evolution of a core gene network for skeletogenesis in chordates. PLoS Genet 4: e1000025. 
R. Chiquet-Ehrismann and R.P. Tucker

Herlyn M, Graeven U, Speicher D, Sela BA, Bennicelli JL, Kath R, Guerry Dt. 1991. Characterization of tenascin secreted by human melanoma cells. Cancer Res 51: 4853-4858.

Herold-Mende C, Mueller MM, Bonsanto MM, Schmitt HP, Kunze S, Steiner HH. 2002. Clinical impact and functional aspects of tenascin-C expression during glioma progression. Int J Cancer 98: 362-369.

Higuchi M, Ohnishi T, Arita N, Hiraga S, Hayakawa T. 1993 Expression of tenascin in human gliomas: Its relation to histological malignancy, tumor dedifferentiation and angiogenesis. Acta Neuropathol 85: 481-487.

Hirata E, Arakawa Y, Shirahata M, Yamaguchi M, Kishi Y, Okada T, Takahashi JA, Matsuda M, Hashimoto N. 2009. Endogenous tenascin-C enhances glioblastoma invasion with reactive change of surrounding brain tissue. Cancer Sci 100: 1451-1459.

Hoffmann K, Sivukhina E, Potschka H, Schachner M, Loscher W, Dityatev A. 2009. Retarded kindling progression in mice deficient in the extracellular matrix glycoprotein tenascin-R. Epilepsia 50: 859-869.

Huang W, Chiquet-Ehrismann R, Moyano JV, Garcia-Pardo A, Orend G. 2001. Interference of tenascin-C with syndecan-4 binding to fibronectin blocks cell adhesion and stimulates tumor cell proliferation. Cancer Res 61: 8586-8594.

Huang Z, Wang D, Ihida-Stansbury K, Jones PL, Martin JF. 2009. Defective pulmonary vascular remodeling in Smad8 mutant mice. Hum Mol Genet 18: 2791-2801.

Ikeshima-Kataoka H, Shen JS, Eto Y, Saito S, Yuasa S. 2008. Alteration of inflammatory cytokine production in the injured central nervous system of tenascin-deficient mice. In Vivo 22: 409-413.

Imai K, Kusakabe M, Sakakura T, Nakanishi I, Okada Y. 1994. Susceptibility of tenascin to degradation by matrix metalloproteinases and serine proteinases. FEBS Lett 352: 216-218.

Irintchev A, Rollenhagen A, Troncoso E, Kiss JZ, Schachner M. 2005. Structural and functional aberrations in the cerebral cortex of tenascin-C deficient mice. Cereb Cortex 15: 950-962.

Ishii K, Imanaka-Yoshida K, Yoshida T, Sugimura Y. 2008. Role of stromal tenascin-C in mouse prostatic development and epithelial cell differentiation. Dev Biol 324: 310-319.

Jahkola T, Toivonen T, Nordling S, von Smitten K, Virtanen I. 1998. Expression of tenascin-C in intraductal carcinoma of human breast: Relationship to invasion. Eur J Cancer 34: 1687-1692.

Jahkola T, Toivonen T, von Smitten K, Blomqvist C, Virtanen I. 1996. Expression of tenascin in invasion border of early breast cancer correlates with higher risk of distant metastasis. Int J Cancer 69: 445-447.

Jinnin M, Ihn H, Asano Y, Yamane K, Trojanowska M, Tamaki K. 2004. Tenascin-C upregulation by transforming growth factor- $\beta$ in human dermal fibroblasts involves Smad3, Sp1, and Ets1. Oncogene 23: 1656-1667.

Jinnin M, Ihn H, Asano Y, Yamane K, Trojanowska M, Tamaki K. 2006. Platelet derived growth factor induced tenascin-C transcription is phosphoinositide 3-kinase/ Akt-dependent and mediated by Ets family transcription factors. J Cell Physiol 206: 718-727.
Joester A, Faissner A. 2001. The structure and function of tenascins in the nervous system. Matrix Biol 20: 13-22.

Jones PL, Jones FS, Zhou B, Rabinovitch M. 1999. Induction of vascular smooth muscle cell tenascin-C gene expression by denatured type I collagen is dependent upon a beta3 integrin-mediated mitogen-activated protein kinase pathway and a 122-base pair promoter element. J Cell Sci 112: 435-445.

Jones FS, Meech R, Edelman DB, Oakey RJ, Jones PL. 2001. Prxl controls vascular smooth muscle cell proliferation and tenascin-C expression and is upregulated with Prx2 in pulmonary vascular disease. Circ Res 89: 131-138.

Kazanis I, Belhadi A, Faissner A, Ffrench-Constant C. 2007. The adult mouse subependymal zone regenerates efficiently in the absence of tenascin-C. J Neurosci 27: 13991-13996.

Kiernan BW, Garcion E, Ferguson J, Frost EE, Torres EM, Dunnett SB, Saga Y, Aizawa S, Faissner A, Kaur R, et al. 1999. Myelination and behaviour of tenascin-C null transgenic mice. Eur J Neurosci 11: 3082-3092.

Kim CH, Bak KH, Kim YS, Kim JM, Ko Y, Oh SJ, Kim KM, Hong EK. 2000. Expression of tenascin-C in astrocytic tumors: Its relevance to proliferation and angiogenesis. Surg Neurol 54: 235-240.

Kondo S, Tang Y, Scheef EA, Sheibani N, Sorenson CM. 2008. Attenuation of retinal endothelial cell migration and capillary morphogenesis in the absence of bcl-2. Am J Physiol Cell Physiol 294: C1521-C1530.

Koyama Y, Kusubata M, Yoshiki A, Hiraiwa N, Ohashi T, Irie S, Kusakabe M. 1998. Effect of tenascin-C deficiency on chemically induced dermatitis in the mouse. I Invest Dermatol 111: 930-935.

Kruse J, Keilhauer G, Faissner A, Timpl R, Schachner M. 1985. The J1 glycoprotein-a novel nervous system cell adhesion molecule of the $\mathrm{L} 2 / \mathrm{HNK}-1$ family. Nature 316: $146-148$.

Lange K, Kammerer M, Hegi ME, Grotegut S, Dittmann A, Huang W, Fluri E, Yip GW, Gotte M, Ruiz C, et al. 2007. Endothelin receptor type B counteracts tenascin-Cinduced endothelin receptor type A-dependent focal adhesion and actin stress fiber disorganization. Cancer Res 67: 6163-6173.

Lee HJ, Jakovcevski I, Radonjic N, Hoelters L, Schachner M, Irintchev A. 2009. Better functional outcome of compression spinal cord injury in mice is associated with enhanced H-reflex responses. Exp Neurol 216: 365-374.

Leins A, Riva P, Lindstedt R, Davidoff MS, Mehraein P, Weis S. 2003. Expression of tenascin-C in various human brain tumors and its relevance for survival in patients with astrocytoma. Cancer 98: 2430-2439.

Leprini A, Gherzi R, Vecchi E, Borsi L, Zardi L, Siri A. 1998. Rat tenascin-R gene: Structure, chromosome location and transcriptional activity of promoter and exon 1. Cytogenet Cell Genet 83: 115-123.

Lotz MM, Burdsal CA, Erickson HP, McClay DR. 1989. Cell adhesion to fibronectin and tenascin: Quantitative measurements of initial binding and subsequent strengthening response. J Cell Biol 109: 1795-1805.

Mackie EJ, Thesleff I, Chiquet-Ehrismann R. 1987. Tenascin is associated with chondrogenic and osteogenic differentiation in vivo and promotes chondrogenesis in vitro. J Cell Biol 105: 2569-2579. 
Tenascins and the Importance of Adhesion Modulation

Mai J, Sameni M, Mikkelsen T, Sloane BF. 2002. Degradation of extracellular matrix protein tenascin-C by cathepsin B: An interaction involved in the progression of gliomas. Biol Chem 383: 1407-1413.

Mao JR, Taylor G, Dean WB, Wagner DR, Afzal V, Lotz JC, Rubin EM, Bristow J. 2002. Tenascin-X deficiency mimics Ehlers-Danlos syndrome in mice through alteration of collagen deposition. Nat Genet 30: 421-425.

Martin D, Brown-Luedi M, Chiquet-Ehrismann R. 2003. Tenascin-C signaling through induction of 14-3-3 tau. J Cell Biol 160: 171-175.

Martina E, Chiquet-Ehrismann R, Brellier F. 2010. Tenascin-W: An extracellular matrix protein associated with osteogenesis and cancer. Int J Biochem Cell Biol 42: 1412-1415.

Martina E, Degen M, Rüegg C, Merlo A, Lino MM, Chiquet-Ehrismann R, Brellier F. 2009. Tenascin-W is a specific marker of glioma-associated blood vessels and stimulates angiogenesis in vitro. FASEB J 24: 778-787.

Maschler S, Grunert S, Danielopol A, Beug H, Wirl G. 2004. Enhanced tenascin-C expression and matrix deposition during Ras/TGF- $\beta$-induced progression of mammary tumor cells. Oncogene 23: 3622-3633.

Matsuda A, Hirota T, Akahoshi M, Shimizu M, Tamari M, Miyatake A, Takahashi A, Nakashima K, Takahashi N, Obara K, et al. 2005. Coding SNP in tenascin-C Fn-III-D domain associates with adult asthma. Hum Mol Genet 14: 2779-2786.

Matsuda A, Yoshiki A, Tagawa Y, Matsuda H, Kusakabe M. 1999. Corneal wound healing in tenascin knockout mouse. Invest Ophthalmol Vis Sci 40: 1071-1080.

Matsumoto K, Hiraiwa N, Yoshiki A, Ohnishi M, Kusakabe M. 2002. Tenascin-C expression and splice variant in habu snake venom-induced glomerulonephritis. Exp Mol Pathol 72: 186-195.

Matsumoto K, Minamitani T, Orba Y, Sato M, Sawa H, Ariga H. 2004. Induction of matrix metalloproteinase- 2 by tenascin-X deficiency is mediated through the c-Jun $\mathrm{N}$-terminal kinase and protein tyrosine kinase phosphorylation pathway. Exp Cell Res 297: 404-414.

Meloty-Kapella CV, Degen M, Chiquet-Ehrismann R, Tucker RP. 2006. Avian tenascin-W: Expression in smooth muscle and bone, and effects on calvarial cell spreading and adhesion in vitro. Dev Dyn 235: 1532-1542.

Meloty-Kapella CV, Degen M, Chiquet-Ehrismann R, Tucker RP. 2008. Effects of tenascin-W on osteoblasts in vitro. Cell Tissue Res 334: 445-455.

Mettouchi A, Cabon F, Montreau N, Dejong V, Vernier P, Gherzi R, Mercier G, Binetruy B. 1997. The c-Juninduced transformation process involves complex regulation of tenascin-C expression. Mol Cell Biol 17: 3202-3209.

Midwood KS, Orend G. 2009. The role of tenascin-C in tissue injury and tumorigenesis. J Cell Commun Signal 3: 287-310.

Midwood KS, Schwarzbauer JE. 2002. Tenascin-C modulates matrix contraction via focal adhesion kinase- and Rho-mediated signaling pathways. Mol Biol Cell 13: 3601-3613.
Midwood K, Sacre S, Piccinini AM, Inglis J, Trebaul A, Chan E, Drexler S, Sofat N, Kashiwagi M, Orend G, et al. 2009. Tenascin-C is an endogenous activator of Toll-like receptor 4 that is essential for maintaining inflammation in arthritic joint disease. Nat Med 15: 774-780.

Midwood KS, Valenick LV, Hsia HC, Schwarzbauer JE. 2004. Coregulation of fibronectin signaling and matrix contraction by tenascin-C and syndecan-4. Mol Biol Cell 15: 5670-5677.

Minamitani T, Ariga H, Matsumoto K. 2000. Transcription factor $\mathrm{Sp} 1$ activates the expression of the mouse tenascinX gene. Biochem Biophys Res Commun 267: 626-631.

Minamitani T, Ariga H, Matsumoto K. 2004a. Deficiency of tenascin-X causes a decrease in the level of expression of type VI collagen. Exp Cell Res 297: 49-60.

Minamitani T, Ikuta T, Saito Y, Takebe G, Sato M, Sawa H, Nishimura T, Nakamura F, Takahashi K, Ariga H, et al. 2004b. Modulation of collagen fibrillogenesis by tenascin-X and type VI collagen. Exp Cell Res 298: 305-315.

Minn AJ, Gupta GP, Siegel PM, Bos PD, Shu W, Giri DD, Viale A, Olshen AB, Gerald WL, Massague J. 2005. Genes that mediate breast cancer metastasis to lung. Nature 436: 518-524.

Montag-Sallaz M, Montag D. 2003. Severe cognitive and motor coordination deficits in tenascin-R-deficient mice. Genes Brain Behav 2: 20-31.

Morel Y, Bristow J, Gitelman SE, Miller WL. 1989. Transcript encoded on the opposite strand of the human steroid 21-hydroxylase/complement component $\mathrm{C} 4$ gene locus. Proc Natl Acad Sci 86: 6582-6586.

Morellini F, Schachner M. 2006. Enhanced novelty-induced activity, reduced anxiety, delayed resynchronization to daylight reversal and weaker muscle strength in tenascin-C-deficient mice. Eur J Neurosci 23: 1255-1268.

Morellini F, Sivukhina E, Stoenica L, Oulianova E, Bukalo O, Jakovcevski I, Dityatev A, Irintchev A, Schachner M. 2010. Improved reversal learning andworking memory and enhanced reactivity to novelty in mice with enhanced GABAergic innervation in the dentate gyrus. Cereb Cortex doi: $101093 /$ cercor/bhq017.

Murphy-Ullrich JE. 2001. The de-adhesive activity of matricellular proteins: Is intermediate cell adhesion an adaptive state? J Clin Invest 107: 785-790.

Murphy-Ullrich JE, Lightner VA, Aukhil I, Yan YZ, Erickson HP, Hook M. 1991. Focal adhesion integrity is downregulated by the alternatively spliced domain of human tenascin [published erratum appears in J Cell Biol 1992 Feb;116:833]. J Cell Biol 115: 1127-1136.

Murphy-Ullrich JE, Pallero MA, Boerth N, Greenwood JA, Lincoln TM, Cornwell TL. 1996. Cyclic GMP-dependent protein kinase is required for thrombospondin and tenascin mediated focal adhesion disassembly. J Cell Sci 109: $2499-2508$.

Nakahara H, Gabazza EC, Fujimoto H, Nishii Y, D’Alessandro-Gabazza CN, Bruno NE, Takagi T, Hayash T, Maruyama J, Maruyama K, et al. 2006. Deficiency of tenascin $C$ attenuates allergen-induced bronchial asthma in the mouse. Eur J Immunol 36: 3334-3345.

Nakao N, Hiraiwa N, Yoshiki A, Ike F, Kusakabe M. 1998. Tenascin-C promotes healing of Habu-snake venominduced glomerulonephritis: Studies in knockout congenic mice and in culture. Am J Pathol 152: 1237-1245. 
R. Chiquet-Ehrismann and R.P. Tucker

Natali PG, Nicotra MR, Bartolazzi A, Mottolese M, Coscia N, Bigotti A, Zardi L. 1990. Expression and production of tenascin in benign and malignant lesions of melanocyte lineage. Int J Cancer 46: 586-590.

Neidhardt J, Fehr S, Kutsche M, Lohler J, Schachner M. 2003. Tenascin-N: Characterization of a novel member of the tenascin family that mediates neurite repulsion from hippocampal explants. Mol Cell Neurosci 23: 193-209.

Nikonenko A, Schmidt S, Skibo G, Bruckner G, Schachner M. 2003. Tenascin-R-deficient mice show structural alterations of symmetric perisomatic synapses in the CA1 region of the hippocampus. J Comp Neurol 456: 338-349.

Nishioka T, Onishi K, Shimojo N, Nagano Y, Matsusaka H, Ikeuchi M, Ide T, Tsutsui H, Hiroe M, Yoshida T, et al. 2010. Tenascin-C may aggravate left ventricular remodeling and function after myocardial infarction in mice. Am J Physiol Heart Circ Physiol 298: H1072-H1078.

Norenberg U, Wille H, Wolff JM, Frank R, Rathjen FG. 1992. The chicken neural extracellular matrix molecule restrictin: Similarity with EGF-, fibronectin type III-, and fibrinogen-like motifs. Neuron 8: 849-863.

Ohta M, Sakai T, Saga Y, Aizawa S, Saito M. 1998. Suppression of hematopoietic activity in tenascin-C-deficient mice. Blood 91: 4074-4083.

Okamura N, Hasegawa M, Nakoshi Y, Iino T, Sudo A, Imanaka-Yoshida K, Yoshida T, Uchida A. 2010. Deficiency of tenascin- $\mathrm{C}$ delays articular cartilage repair in mice. Osteoarthritis Cartilage 18: 839-848.

Orend G, Chiquet-Ehrismann R. 2006. Tenascin-C induced signaling in cancer. Cancer Lett 244: 143-163.

Pesheva P, Spiess E, Schachner M. 1989. J1-160 and J1-180 are oligodendrocyte-secreted nonpermissive substrates for cell adhesion. J Cell Biol 109: 1765-1778.

Pesheva P, Probstmeier R, Skubitz AP, McCarthy JB, Furcht LT, Schachner M. 1994. Tenascin-R (J1 160/180) inhibits fibronectin-mediated cell adhesion-functional relatedness to tenascin-C. J Cell Sci 107: 2323-2333.

Putnam NH, Srivastava M, Hellsten U, Dirks B, Chapman J, Salamov A, Terry A, Shapiro H, Lindquist E, Kapitonov VV, et al. 2007. Sea anemone genome reveals ancestral eumetazoan gene repertoire and genomic organization. Science 317: 86-94.

Putthoff P, Akyuz N, Kutsche M, Zardi L, Borgmeyer U, Schachner M. 2003. Structure of the murine tenascin-R gene and functional characterisation of the promoter. Biochem Biophys Res Commun 308: 940-949.

Rathjen FG, Wolff JM, Chiquet-Ehrismann R. 1991. Restrictin: A chick neural extracellular matrix protein involved in cell attachment co-purifies with the cell recognition molecule F11. Development 113: 151-164.

Reardon DA, Zalutsky MR, Bigner DD. 2007. Antitenascin$\mathrm{C}$ monoclonal antibody radioimmunotherapy for malignant glioma patients. Expert Rev Anticancer Ther 7: 675-687.

Roth-Kleiner M, Hirsch E, Schittny JC. 2004. Fetal lungs of tenascin-C-deficient mice grow well, but branch poorly in organ culture. Am J Respir Cell Mol Biol 30: 360-366.

Ruiz C, Huang W, Hegi ME, Lange K, Hamou MF, Fluri E, Oakeley EJ, Chiquet-Ehrismann R, Orend G. 2004
Growth promoting signaling by tenascin-C [corrected]. Cancer Res 64: 7377-7385.

Saga Y, Yagi T, Ikawa Y, Sakakura T, Aizawa S. 1992. Mice develop normally without tenascin. Genes Dev 6: $1821-1831$.

Saghatelyan AK, Dityatev A, Schmidt S, Schuster T, Bartsch U, Schachner M. 2001. Reduced perisomatic inhibition, increased excitatory transmission, and impaired longterm potentiation in mice deficient for the extracellular matrix glycoprotein tenascin-R. Mol Cell Neurosci 17: 226-240.

Sakai T, Furukawa Y, Chiquet-Ehrismann R, Nakamura M, Kitagawa S, Ikemura T, Matsumoto K. 1996. Tenascin-X expression in tumor cells and fibroblasts: Glucocorticoids as negative regulators in fibroblasts. J Cell Sci 109: 2069-2077.

Sakai T, Kawakatsu H, Furukawa Y, Saito M. 1995. Regulation of EGF-induced tenascin-C by steroids in tenascin-C non-producing human carcinoma cells. Int $\mathrm{J}$ Cancer 63: 720-725.

Sarasa-Renedo A, Tunc-Civelek V, Chiquet M. 2006. Role of RhoA/ROCK-dependent actin contractility in the induction of tenascin-C by cyclic tensile strain. Exp Cell Res 312: $1361-1370$.

Sarkar S, Nuttall RK, Liu S, Edwards DR, Yong VW. 2006. Tenascin-C stimulates glioma cell invasion through matrix metalloproteinase-12. Cancer Res 66: 1177111780 .

Scharer CD, McCabe CD, Ali-Seyed M, Berger MF, Bulyk ML, Moreno CS. 2009. Genome-wide promoter analysis of the SOX4 transcriptional network in prostate cancer cells. Cancer Res 69: 709-717.

Scherberich A, Tucker RP, Degen M, Brown-Luedi M, Andres AC, Chiquet-Ehrismann R. 2005. Tenascin-W is found in malignant mammary tumors, promotes $\alpha 8$ integrin-dependent motility and requires p38MAPK activity for BMP-2 and TNF- $\alpha$ induced expression in vitro. Oncogene 24: 1525-1532.

Scherberich A, Tucker RP, Samandari E, Brown-Luedi M, Martin D, Chiquet-Ehrismann R. 2004. Murine tenascin-W: A novel mammalian tenascin expressed in kidney and at sites of bone and smooth muscle development. J Cell Sci 117: 571-581.

Schliemann C, Wiedmer A, Pedretti M, Szczepanowski M, Klapper W, Neri D. 2009. Three clinical-stage tumor targeting antibodies reveal differential expression of oncofetal fibronectin and tenascin-C isoforms in human lymphoma. Leuk Res 33: 1718-1722.

Siri A, Knauper V, Veirana N, Caocci F, Murphy G, Zardi L. 1995. Different susceptibility of small and large human tenascin-C isoforms to degradation by matrix metalloproteinases. J Biol Chem 270: 8650-8654.

Sivasankaran B, Degen M, Ghaffari A, Hegi ME, Hamou MF, Ionescu MC, Zweifel C, Tolnay M, Wasner M, Mergenthaler S, et al. 2009. Tenascin-C is a novel RBPJ kappa-induced target gene for Notch signaling in gliomas. Cancer Res 69: 458-465.

Sykova E, Vorisek I, Mazel T, Antonova T, Schachner M. 2005. Reduced extracellular space in the brain of tenascin-R- and HNK-1-sulphotransferase deficient mice. Eur J Neurosci 22: 1873-1880. 
Tenascins and the Importance of Adhesion Modulation

Tamaoki M, Imanaka-Yoshida K, Yokoyama K, Nishioka T, Inada H, Hiroe M, Sakakura T, Yoshida T. 2005. Tenascin-C regulates recruitment of myofibroblasts during tissue repair after myocardial injury. Am J Pathol 167: 71-80.

Tanaka K, Hiraiwa N, Hashimoto H, Yamazaki Y, Kusakabe M. 2004. Tenascin-C regulates angiogenesis in tumor through the regulation of vascular endothelial growth factor expression. Int J Cancer 108: 31-40.

Tavazoie SF, Alarcon C, Oskarsson T, Padua D, Wang Q, Bos PD, Gerald WL, Massague J. 2008. Endogenous human microRNAs that suppress breast cancer metastasis. Nature 451: 147-152.

Treloar HB, Ray A, Dinglasan LA, Schachner M, Greer CA. 2009. Tenascin-C is an inhibitory boundary molecule in the developing olfactory bulb. J Neurosci 29: 94059416.

Tsunoda T, Inada H, Kalembeyi I, Imanaka-Yoshida $\mathrm{K}$, Sakakibara M, Okada R, Katsuta K, Sakakura T, Majima Y, Yoshida T. 2003. Involvement of large tenascin-C splice variants in breast cancer progression. Am J Pathol 162: 1857-1867.

Tucker RP. 2001. Abnormal neural crest cell migration after the in vivo knockdown of tenascin-C expression with morpholino antisense oligonucleotides. Dev Dyn 222: 115-119.

Tucker RP, Chiquet-Ehrismann R. 2009a. Evidence for the evolution of tenascin and fibronectin early in the chordate lineage. Int J Biochem Cell Biol 41: 424-434.

Tucker RP, Chiquet-Ehrismann R. 2009b. The regulation of tenascin expression by tissue microenvironments. Biochim Biophys Acta 1793: 888-892.

Tucker RP, McKay SE. 1991. The expression of tenascin by neural crest cells and glia. Development 112: 1031-1039.

Tucker RP, Drabikowski K, Hess JF, Ferralli J, Chiquet-Ehrismann R, Adams JC. 2006. Phylogenetic analysis of the tenascin gene family: Evidence of origin early in the chordate lineage. BMC Evol Biol 6: 60.

Wang B, Ling S, Lin WC. 2010. 14-3-3Tau regulates Beclin 1 and is required for autophagy. PLoS One 5: e10409.

Watanabe G, Nishimori H, Irifune H, Sasaki Y, Ishida S, Zembutsu H, Tanaka T, Kawaguchi S, Wada T, Hata J, et al. 2003. Induction of tenascin-C by tumor-specific EWS-ETS fusion genes. Genes Chromosomes Cancer 36: $224-232$.
Weber P, Bartsch U, Rasband MN, Czaniera R, Lang Y, Bluethmann H, Margolis RU, Levinson SR, Shrager P, Montag D, et al. 1999. Mice deficient for tenascin-R display alterations of the extracellular matrix and decreased axonal conduction velocities in the CNS. J Neurosci 19: $4245-4262$.

Weber P, Montag D, Schachner M, Bernhardt RR. 1998. Zebrafish tenascin-W, a new member of the tenascin family. J Neurobiol 35: 1-16.

Wenk MB, Midwood KS, Schwarzbauer JE. 2000. TenascinC suppresses Rho activation. J Cell Biol 150: 913-920.

Whittaker CA, Bergeron KF, Whittle J, Brandhorst BP, Burke RD, Hynes RO. 2006. The echinoderm adhesome. Dev Biol 300: 252-266.

Wijesuriya SD, Bristow J, Miller WL. 2002. Localization and analysis of the principal promoter for human tenascin-X. Genomics 80: 443-452.

Williams SA, Schwarzbauer JE. 2009. A shared mechanism of adhesion modulation for tenascin-C and fibulin-1. Mol Biol Cell 20: 1141-1149.

Yamada KM, Yamada SS, Pastan I. 1975. The major cell surface glycoprotein of chick embryo fibroblasts is an agglutinin. Proc Natl Acad Sci 72: 3158-3162.

Yamamoto H, Cho SW, Song SJ, Hwang HJ, Lee MJ, Kim JY, Jung HS. 2005. Characteristic tissue interaction of the diastema region in mice. Arch Oral Biol 50: 189-198.

Yamamoto K, Dang QN, Kennedy SP, Osathanondh R, Kelly RA, Lee RT. 1999. Induction of tenascin-C in cardiac myocytes by mechanical deformation. Role of reactive oxygen species. J Biol Chem 274: $21840-$ 21846.

Yeh J, Green LM, Jiang TX, Plikus M, Huang E, Chang RN, Hughes MW, Chuong CM, Tuan TL. 2009. Accelerated closure of skin wounds in mice deficient in the homeobox gene Msx2. Wound Repair Regen 17: 639-648.

Zagzag D, Friedlander DR, Miller DC, Dosik J, Cangiarella J, Kostianovsky M, Cohen H, Grumet M, Greco MA. 1995. Tenascin expression in astrocytomas correlates with angiogenesis. Cancer Res 55: 907-914.

Zhang G, Cohn MJ. 2006. Hagfish and lancelet fibrillar collagens reveal that type II collagen-based cartilage evolved in stem vertebrates. Proc Natl Acad Sci 103: 16829-16833. 


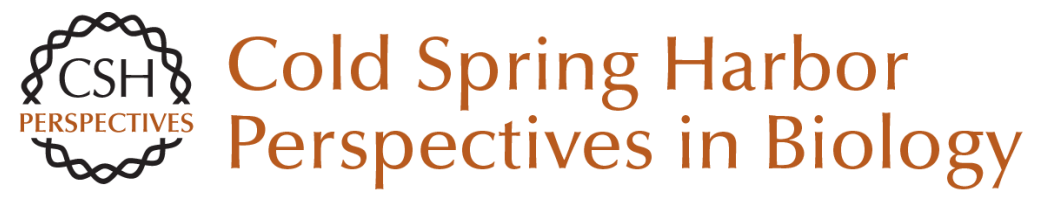

\section{Tenascins and the Importance of Adhesion Modulation}

Ruth Chiquet-Ehrismann and Richard P. Tucker

Cold Spring Harb Perspect Biol 2011; doi: 10.1101/cshperspect.a004960 originally published online February 23, 2011

\section{Subject Collection Extracellular Matrix Biology}

Extracellular Matrix in Development: Insights from Mechanisms Conserved between Invertebrates and Vertebrates Nicholas H. Brown

Extracellular Matrix Proteins in Hemostasis and Thrombosis

Wolfgang Bergmeier and Richard O. Hynes

The Thrombospondins Josephine C. Adams and Jack Lawler

Cross Talk among TGF- $\beta$ Signaling Pathways, Integrins, and the Extracellular Matrix John S. Munger and Dean Sheppard

Heparan Sulfate Proteoglycans Stephane Sarrazin, William C. Lamanna and Jeffrey D. Esko

The Collagen Family Sylvie Ricard-Blum

Tenascins and the Importance of Adhesion Modulation

Ruth Chiquet-Ehrismann and Richard P. Tucker

Integrin Structure, Activation, and Interactions

lain D. Campbell and Martin J. Humphries
Extracellular Matrix Degradation and Remodeling in Development and Disease

Pengfei Lu, Ken Takai, Valerie M. Weaver, et al.

Overview of the Matrisome--An Inventory of Extracellular Matrix Constituents and Functions Richard O. Hynes and Alexandra Naba

Integrins in Cell Migration Anna Huttenlocher and Alan Rick Horwitz

Fibronectins, Their Fibrillogenesis, and In Vivo

Functions Jean E. Schwarzbauer and Douglas W. DeSimone

Extracellular Matrix: Functions in the Nervous System

Claudia S. Barros, Santos J. Franco and Ulrich Müller

Molecular Architecture and Function of Matrix

Adhesions

Benjamin Geiger and Kenneth M. Yamada

Cell-Extracellular Matrix Interactions in Normal and Diseased Skin

Fiona M. Watt and Hironobu Fujiwara

Genetic Analyses of Integrin Signaling

Sara A. Wickström, Korana Radovanac and Reinhard Fässler

For additional articles in this collection, see http://cshperspectives.cshlp.org/cgi/collection/

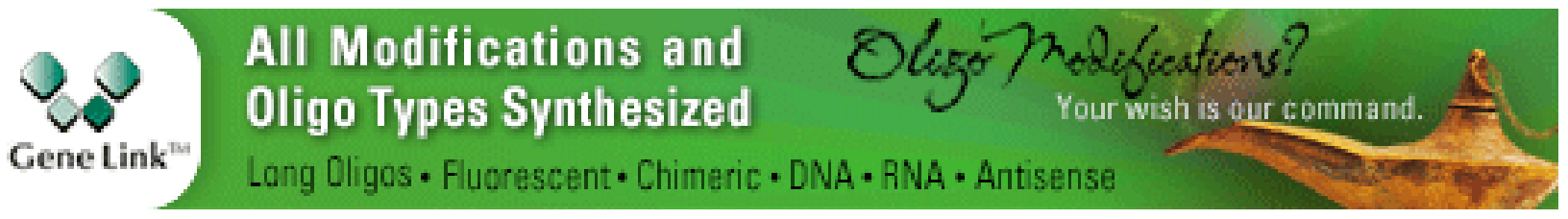

Copyright @ 2011 Cold Spring Harbor Laboratory Press; all rights reserved 